\title{
STANDARDIZATION OF A PROTOCOL TO EXTRACT AND ANALYZE CHLOROPHYLL A AND CAROTENOIDS IN Gracilaria tenuistipitata VAR. LIUI. ZHANG AND XIA (RHODOPHYTA)
}

\author{
Priscila Bezerra Torres ${ }^{l}$, Fungyi Chow ${ }^{l}$, Cláudia Maria Furlan ${ }^{2}$, Fernanda Mandelli ${ }^{2}$, \\ Adriana Mercadante ${ }^{2}$ and Déborah Yara Alves Cursino dos Santos ${ }^{1, *}$ \\ Instituto de Biociências da Universidade de São Paulo - Departamento de Botânica \\ (Rua do Matão 277, 05508-090 São Paulo, SP, Brasil) \\ Instituto de Biologia da Universidade Estadual de Campinas - Unicamp \\ Cidade Universitária Zeferino Vaz \\ (Rua Monteiro Lobato, 255, 13083-862 Campinas, SP, Brasil)
}

*Corresponding author: dyacsan@ib.usp.br

http://dx.doi.org/10.1590/S1679-87592014068106201

\begin{abstract}
A B S TR ACT
Chlorophyll $a$ and carotenoids are important pigments in photosynthesis. Several studies have been published describing extraction and analysis protocols of these pigments, mainly in vascular plant species. This study standardizes an extraction and analysis protocol of these substances in Gracilaria tenuistipitata var. liui, a red seaweed. Apical portions grown in vitro were triturated in liquid nitrogen. Extracts were prepared in $1.5 \mathrm{~mL}$ solvent and centrifuged. Quantitative and qualitative analyses of pigments were performed by UV/visible light spectrophotometry and high performance liquid chromatography (HPLC) and HPLC coupled to mass spectrometry (HPLC-MS). The parameters assessed were: minimum biomass, best extraction solvent, and number of extraction steps. Methanol was the most efficient solvent, and $50 \mathrm{mg}$ fresh biomass was the amount of sample indicated, submitted to one single extraction step. No significant differences were observed in levels of these pigments by UV-visible light spectrophotometry and HPLC. However, HPLC or HPLC-MS are required to identify the different carotenoids present in this seaweed species.
\end{abstract}

\section{R E S UMO}

Clorofila $a$ e carotenoides são importantes pigmentos da fotossíntese. Na literatura são encontrados vários protocolos de extração e análise desses pigmentos utilizando, principalmente, plantas vasculares. O objetivo deste estudo foi padronizar uma metodologia de extração e análise dessas substâncias em uma macroalga vermelha, Gracilaria tenuistipitata var. liui. Amostras de talos gametofíticos cultivados in vitro foram trituradas em nitrogênio líquido, extraídas em $1,5 \mathrm{~mL}$ de solvente, centrifugadas e os pigmentos analisados quantitativamente e qualitativamente através de espectrofotometria de UV/visível, cromatografia liquida de alta eficiência (CLAE) e CLAE-acoplada a espectrometria de massas (CLAE-EM). Foram testados os parâmetros massa mínima, solvente para extração e número de extrações. Dentre os solventes testados, o metanol foi o mais eficiente, sendo $50 \mathrm{mg}$ de material fresco a massa mínima indicada para ser submetida a somente uma extração. Não foram encontradas diferenças significativas na quantificação desses pigmentos comparando-se os dados obtidos em espectrofotometria de UV/visível com os de CLAE. No entanto, para a identificação dos diferentes carotenoides e suas quantificações são necessárias CLAE ou CLAE-EM.

Descriptors: Gracilaria tenuistipitata, Chlorophyll a, Carotenoids, UV-visible light spectrophotometry, HPLC.

Descritores: Gracilaria tenuistipitata, Clorofila a, Carotenoides, Espectrometria UV-visível, CLAE.

\section{INTRODUCTION}

With rare exceptions, the most important and common pigment in photosynthesis is reaction center chlorophyll $a(\operatorname{chl} a)$. Chl $a$ plays a direct role in energy transduction. Yet, when this pigment is present in the antenna complex, it is responsible for the transfer of the absorbed light energy to the reaction centers, similarly to carotenoids, to other chlorophylls 
( $b, \quad c$ and $d$ ) and phycobilins, all of which are considered accessory pigments (RAVEN et al., 2007). Photosynthetic organisms differ in these pigments' composition, which leads to the distinct roles they play in photosynthesis.

Studies on the biology, distribution and abundance of photosynthetic organisms usually require the analysis of these pigments (as MARINHOSORIANO, 2012, for instance). In this sense, the knowledge of these pigments' behavior under different environmental conditions is essential in investigations on the establishment of economically important cultures, as in the context of mariculture activities. The qualitative and quantitative changes these pigments undergo represent adaptation mechanisms to a new condition, and may help understand these organisms' development and growth patterns (SCHMIDT et al., 2010). From this perspective, investigations on carotenoids and chlorophylls are an important part of studies focused on economic applications and in research more particularly directed to ecological issues. However, these studies require the extraction and analysis of these substances, which are quite unstable not only at high temperatures, but also when exposed to light and to oxygen (BORSARELLI; MERCADANTE, 2010), an obstacle to the development of reliable, reproducible analysis protocols.

Several studies have described methodologies to analyze these pigments. These investigative efforts are based on the evaluation of parameters such as solvents, number of extraction steps and required biomass, all of which are aspects that vary across different organisms. Moreover, an array of techniques is used in the analysis and quantification of these pigments, among which are UV/visible light spectrophotometry and, more recently, high performance liquid chromatography (HPLC) and/or high performance liquid chromatography coupled with tandem mass spectrometry (HPLC-MS). A considerable number of these methodologies was especially developed to analyze vascular plant species or phytoplankton, as reported in recent reviews (GUEDES et al., 2011; ARVAYO-ANRÍQUZ et al., 2013), and, as a rule, studies on seaweed are conducted using these methodologies. However, it is known that all these parameters are influenced by the types of pigments present and the constituents of the plant matrix (KOPEC et al., 2012).

In this scenario, the present study aimed to set up a methodology to optimize the extraction, quantification and identification of chl $a$ and carotenoids in Gracilaria tenuistipitata var. liui. Zhang and Xia, a red macroalga species, which is an important raw material in the production of agar and is also used as a model in physiological and molecular studies.

\section{Material AND Methods}

\section{Materials and Cultivation Conditions}

Apical tips of Gracilaria tenuistipitata var. liui Zhang and Xia tetrasporophytic phase were grown from material labeled BG0062, provided by the germplasm bank of Laboratory of Seaweed Studies Edison José de Paula, Institute of Biosciences, University of São Paulo, SP, Brazil.

The seaweed used was acclimated under controlled conditions (temperature: $25 \pm 1^{\circ} \mathrm{C}$; light irradiance: $60 \pm 5 \mu \mathrm{mol}$ photons. $\mathrm{m}^{-2} . \mathrm{s}^{-1}$; photoperiod: 14 $\mathrm{h}$ light, $10 \mathrm{~h}$ dark; aeration at intermittent $30 \mathrm{~min}$ intervals; culture medium: $10 \mathrm{~g} \mathrm{FW/} 1 \mathrm{~L}$ culture medium enriched with Von Stosch solution 100\%, modified from Edwards (1970) and according to Ursi and Plastino (2001). Culture media were replaced weekly. After 2 months, $3 \mathrm{~cm}$ apical tips were weighed, frozen in liquid nitrogen and stored in a freezer at $-80^{\circ} \mathrm{C}$ for subsequent analyses.

\section{Parameters Tested and Extraction of Chlorophyll A and Total Carotenoids}

Acetone, acetone:water $(9: 1 \quad \mathrm{v} / \mathrm{v})$, acetone:water $(8: 2, \mathrm{v} / \mathrm{v})$, dimethylformamide (DMF), dimethylsulphoxide (DMSO), ethyl ether, hexane, methanol and toluene were tested in the quest for the most efficient solvent in the extraction procedure. In dim light, $1.5 \mathrm{~mL}$ of each solvent was added to a 50 mg sample of the frozen apical tips previously pulverized in liquid nitrogen. Then, the mixtures were homogenized in a vortex shaker, centrifuged $(20,800$ $\left.g, 4^{\circ} \mathrm{C}, 5 \mathrm{~min}\right)$ and immediately analyzed by UV/visible light spectrophotometry and/or HPLC.

After the best solvent was established, tests using different fresh biomass quantities (100 mg, 50 $\mathrm{mg}$ and $25 \mathrm{mg}$ ) were carried out. Then, the number of extraction steps was determined by re-extracting the resulting residue after centrifugation, plus one extraction step using $1.5 \mathrm{~mL}$, and one using $1 \mathrm{~mL}$.

\section{Quantification of Total Carotenoids and Chlorophyll A by UV/Visible Light Spectrophotometry}

The extracts obtained as above were immediately submitted to screening in a UV/visible light spectrometer (UV-1650 PC, Shimadzu) between $400 \mathrm{~nm}$ and $700 \mathrm{~nm}$. The absorbance values were used to calculate the levels of chl $a$ and total carotenoids according to the corresponding equations, adapted for red algae characteristics (Table 1). 
Table 1. Equations used to determine chl $a$ and total carotenoids, modified for red algae.

\begin{tabular}{|c|c|c|}
\hline Solvent & Chl $a\left(\mu \mathrm{g} . \mathrm{mL}^{-1}\right)$ & Total carotenoids $\left(\mu \mathrm{g} . \mathrm{mL}^{-1}\right)$ \\
\hline Acetone & $10.82 \times$ Abs661.6 ${ }^{1}$ & $(1000 \times$ Abs $470-1.90 \times$ Chl $a) / 214^{1}$ \\
\hline Acetone $90 \%$ & $11.41 \times$ Abs664 2 & $(1000 \times$ Abs $470-2.77 \times \mathrm{Chl} a) / 213^{3}$ \\
\hline Acetone $80 \%$ & $11.59 \times$ Abs $663^{1}$ & $(1000 \times \mathrm{Abs} 470-1.82 \times \mathrm{Chl} a) / 180^{1}$ \\
\hline DMF & $11.06 \times$ Abs664 ${ }^{3}$ & $(1000 \times$ Abs $480-0.89 \times \mathrm{Chl} a) / 245^{3}$ \\
\hline $\begin{array}{l}\text { DMSO } \\
\text { Diethyl ether }\end{array}$ & $\begin{array}{l}11.35 \times \mathrm{Abs}_{665^{3}}^{3} \\
9.91 \times \mathrm{Abs}_{6} 62^{3}\end{array}$ & $\begin{array}{l}(1000 \times \text { Abs } 480-2.14 \times C h l a) / 220^{3} \\
(1000 \times \text { Abs } 470-1.43 \times \text { Chl } a) / 205^{1}\end{array}$ \\
\hline Methanol & $12.61 \times$ Abs66 ${ }^{1}$ & $(1000 \times$ Abs $470-1.63 \times$ Chl $a) / 221^{1}$ \\
\hline
\end{tabular}

${ }^{1}$ modified from Lichtenthaler and Buschmann (2001); ${ }^{2}$ modified from Jeffrey and Humphrey (1975); ${ }^{3}$ modified from Wellburn (1994). Abs = absorbance. Chl $a=\operatorname{chl} a$ concentration in $\mu \mathrm{g} \cdot \mathrm{mL}^{-1}$.

High Performance Liquid Chromatography (HPLC)

Fifty-microliter aliquots of extract were immediately analyzed by HPLC in a chromatographer (HP1200) coupled to a diode array detector in a $\mathrm{C}_{30}$ reverse phase column $(5 \mu \mathrm{m}, 250 \mathrm{~mm}$ x $4.6 \mathrm{~mm}$ i.d.; Ultracarb ODS). Chromatograms were processed at $\lambda$ $=450 \mathrm{~nm}$. The mobile phase was a gradient of methylterc-butyl ether (MTBE) (A) in methanol (B) following the program: $5 \% \mathrm{~A}(0 \mathrm{~min}), 70 \% \mathrm{~A}(30$ $\mathrm{min}), 50 \%$ A $(50 \mathrm{~min})$. The mobile phase flux was kept constant at $0.9 \mathrm{~mL} \cdot \mathrm{min}^{-1}$ and the column temperature was adjusted to $29^{\circ} \mathrm{C}$ (FARIA et al., 2009).

The pigments were quantified by HPLC using external calibration curves constructed for chl $a$ and zeaxanthin (the main carotenoid in $G$. tenuistipitata var. liui). The curves were constructed using standard solutions of known concentrations (chl a: $3.31-33.12 \mu \mathrm{g} . \mathrm{mL}^{-1}$; zeaxanthin: $0.51-5.16$ $\mu \mathrm{g} . \mathrm{mL}^{-1}$ ) and analyzed by HPLC under the same conditions as the samples. These concentrations were correlated with the respective peak areas (obtained using the chromatograms) by simple linear regression $\left(\mathrm{R}^{2} \geq 0.99\right)$.

\section{Identification of the Photosynthetic Pigments}

The carotenoids and chl $a$ in G. tenuistipitata var. liui were characterized using HPLC with a diode array detector coupled to a mass spectrometer (HPLCMS/MS) in a chromatographer (LC-20AD, Shimadzu) with a $m / z$ ion trap analyzer and APCI ionization source in the positive mode (Esquire 4000, Bunker Daltonics). The UV/visible light spectra were obtained at $200 \mathrm{~nm}$ and $800 \mathrm{~nm}$, and chromatograms were processed at $\lambda=450 \mathrm{~nm}$. The parameters of the mass spectrometer were adjusted according to Rosso and Mercadante (2007): APCI positive mode, corona current $4,000 \mathrm{nA}$, source temperature $450^{\circ} \mathrm{C}, \mathrm{N}_{2}$ as dissecating gas at $350^{\circ} \mathrm{C}$ and $5 \mathrm{~mL} \cdot \mathrm{min}^{-1}$ and as nebulizing gas at $60 \mathrm{psi}, \mathrm{MS} / \mathrm{MS}$ fragmentation energy
$1.4 \mathrm{~V}$. The mass spectra were acquired at a $\mathrm{m} / \mathrm{z}$ interval of $100-1,000$. Carotenoids were separated in a $\mathrm{C}_{30}$ YMC columns $(5 \mu \mathrm{m}, 250 \mathrm{~mm} \times \mathrm{m} 4.6 \mathrm{~mm}$ i.d.) (Waters) using a mobile phase as described above.

The carotenoids and chl $a$ were identified according to the retention times in the $\mathrm{C}_{30}$ column, the UV/visible spectra $\left(\lambda_{\max }\right.$, fine structure, cis peak intensity) and mass spectra, based on comparison with published data (GAUTHIER-JACQUES et al., 2001; VAN BREEMEN et al., 2011) and confirmed by comparison with the retention times of standards (chl $a$ acquired from Sigma-Aldrich and carotenoids acquired from CaroteNature).

\section{Statistical Analyses}

All experiments were carried out in triplicate. The analysis of variance (ANOVA) with $\alpha$ at $5 \%$ was used to detect the differences between total carotenoid and chl $a$ mean contents in each experiment. When this difference was detected, the Tukey test $(\alpha=5 \%)$ assessed the conditions under which these differences were observed. The statistical analyses were conducted using the Minitab ${ }^{\mathrm{TM}}$ 16.1.0 software.

\section{Results AND Discussion}

\section{Parameters Tested: Solvents, Minimum Biomass, Number of Extraction Steps}

The absorption spectra of extracts showed that the most intense absorption values, between 440 $\mathrm{nm}$ and $500 \mathrm{~nm}$ (a range that best represents carotenoids) were obtained when DMF, DMSO, methanol and acetone were used (Fig. 1). On the other hand, less intense absorption values in this range were observed using acetone $80 \%$, acetone $90 \%$ and mainly ethyl ether. These results were observed also for absorption between $650 \mathrm{~nm}$ and $700 \mathrm{~nm}$ (the interval that best represents chl a) (Fig. 1). 


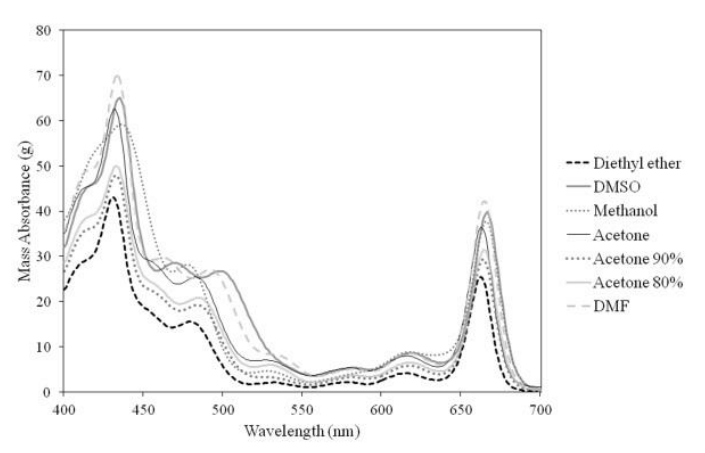

Fig. 1. Mass absorbance spectra of extracts using different solvents to extract photosynthetic pigments.

When the concentrations of pigments were analyzed using the formulas given in Table 1, the least efficient solvents to extract chl $a$ and total carotenoids were acetone $80 \%$, acetone $90 \%$ and, mainly, ethyl ether, in agreement with the previous results, while the best solvent was methanol (Table 2). Apart from being the most efficient solvent, another advantage of methanol is the compatibility with most mobile phases used in the analyses of pigments by HPLC, which minimizes the unfavorable interaction between the solute, the solvent injected and the mobile phase. This prevents poorly resolved peaks and affords higher reproducibility to results (KHACHIK, 2009). The findings observed when DMSO was used suggest that this solvent may be an excellent alternative to methanol, while DMF seems to be a good choice only in the efficient extraction of chl $a$, since carotenoid levels extracted with DMF were low. As opposed to DMF, acetone was efficient in the extraction of carotenoids, but not chl $a$ (Table 2).

Table 2. Mean total carotenoids and chl $a$ levels in Gracilaria tenuistipitata var. liui. Zhang and Xia fresh biomass $\left(\mu \mathrm{g} . \mathrm{g}^{-1}\right)$ for different solvents used in extraction. Values are presented as mean \pm standard deviation for $n=3$. Values followed by one same letter in a column do not differ (one-factor ANOVA and Tukey test, $p<0.05$ ).

\begin{tabular}{|c|c|c|}
\hline Solvent & Total carotenoid $\left(\mu \mathrm{g} \cdot \mathrm{g}^{-1}\right)$ & Chl $a\left(\mu \mathrm{g} . \mathrm{g}^{-1}\right)$ \\
\hline Acetone & $162.28 \pm 13.26^{\mathrm{ab}}$ & $589.95 \pm 36.40^{\mathrm{bc}}$ \\
\hline $\begin{array}{l}\text { Acetone } \\
80 \%\end{array}$ & $144.47 \pm 16.29^{b c}$ & $540.11 \pm 47.14^{\mathrm{c}}$ \\
\hline $\begin{array}{l}\text { Acetone } \\
90 \%\end{array}$ & $121.61 \pm 6.78^{\mathrm{cd}}$ & $502.47 \pm 28.62^{\mathrm{c}}$ \\
\hline DMF & $149.17 \pm 3.97^{\mathrm{abc}}$ & $689.04 \pm 21.02^{\mathrm{a}}$ \\
\hline DMSO & $169.88 \pm 9.36^{\mathrm{ab}}$ & $662.48 \pm 25.86^{\mathrm{ab}}$ \\
\hline $\begin{array}{l}\text { Diethyl } \\
\text { ether }\end{array}$ & $102.31 \pm 8.43^{\mathrm{d}}$ & $376.54 \pm 36.19^{d}$ \\
\hline Methanol & $177.08 \pm 7.46^{\mathrm{a}}$ & $715.18 \pm 29.73^{\mathrm{a}}$ \\
\hline
\end{tabular}

The pigment levels extracted using hexane and toluene were close to zero, showing that, at least for G. tenuistipitata var. liui, apolar solvents do not produce good extraction results. These solvents, especially toluene and hexane, are not commonly used to extract pigments from seaweed, in spite of the fact that carotenoids are typically liposoluble. This may be because these assays usually are carried out using fresh biomass, which presents high water contents, a typical characteristic of sea organisms. In turn, these water contents form a barrier against penetration of these solvents, a characteristic that may explain why the more polar solvents presented the best extraction results, since they break more easily into the fresh biomass. Another explanation for these results is the carotenoid composition of the seaweed species studied, which, as discussed below, has high levels of zeaxanthin, a hydroxylated compound that tends to be more soluble in less apolar solvents (ISHIDA; CHAPMAN, 2009).

Acetone was largely used as a solvent in the pioneering studies on this subject in the 1970s and 1980s. Currently, methanol (KELMAN et al., 2012), DMSO (KOPECKY et al., 2000) and DMF (WRIGHT et al., 1997) have frequently been used in studies on a variety of species. However, although DMF is less volatile and thus less flammable than the other solvents used, its carcinogenic effects stand out as a substantial disadvantage.

As discussed above, our results indicate that methanol is the most efficient solvent to extract carotenoids and chl $a$ in G. tenuistipitata var. liui. Yet, it should be remembered that solvent efficiency to extract pigments may vary across different species of photosynthetic organisms as well as across the organs analyzed, depending on the composition of the cell walls of these organs (KOPEC et al., 2012).

The adequate amount of biomass obtained for studies on some macroalga species cultivated in the laboratory is a limiting factor concerning the directions these studies take and the definition of the number of repeats in an assay. In this sense, after the best solvent to extract carotenoids and chl $a$ was determined, tests using different amounts of $G$. tenuistipitata var. liui $(25 \mathrm{mg}, 50 \mathrm{mg}$ and $100 \mathrm{mg}$ in $1.5 \mathrm{~mL}$ methanol) were carried out to establish the minimum amount of biomass affording conclusive results in this protocol. In this sense, the amount of carotenoids and chl $a$ extracted showed a direct correlation with the amount of biomass used for the extraction (Table 3), with simple linear regression of 0.98 for carotenoids and 0.99 for chl $a$. When mean amounts of these pigments are considered, no significant differences were observed when $50 \mathrm{mg}$ and $100 \mathrm{mg}$ of biomass were used, though the highest total carotenoid level was obtained using the $50 \mathrm{mg}$ biomass sample (Table 3 ). The analyses carried out using $25 \mathrm{mg}$ presented the highest coefficient of variation $(8.35 \%)$ and the lowest pigment concentrations. Carnicas et al. (1999), in a study on 
photostress in this seaweed species, used $100 \mathrm{mg}$ of biomass. Therefore, in the present study, the minimum mass to extract total carotenoids and $\operatorname{chl} a$ from $G$. tenuistipitata var. liui was $50 \mathrm{mg}$ for $1.5 \mathrm{~mL}$ of solvent, since the results using this setting were as efficient - or more - than those obtained using $100 \mathrm{mg}$ of biomass.

After determining the ideal solvent and the minimum biomass, assays using different numbers of extractions were carried out. The amounts of chl $a$ and of total carotenoids obtained in each extraction were individually added to the previous value to find total values (Table 4). One single extraction with $50 \mathrm{mg}$ of fresh biomass and $1.5 \mathrm{~mL}$ of methanol was sufficient to extract, on average, $95.04 \%$ of chl $a$ and $94.38 \%$ of total carotenoids. The second extraction added $3.36 \%$ of chl $a$ and $3.50 \%$ of total carotenoids, while the third extraction contributed with $1.60 \%$ of chl $a$ and $2.12 \%$ of total carotenoids. Although the sequence of extraction steps produced higher amounts of pigments, no significant variations were observed in total pigment amounts obtained adding the second and the third step; in other words, one extraction procedure is enough, which means that, as far as cost-benefit is concerned, time and solvents may be saved using one single extraction procedure.

Quantification of Pigments Using UV/Visible Light Spectrometry and HPLC and Carotenoid Identification

Total carotenoids and chl $a$ detected in $G$. tenuistipitata var. liui using HPLC accounted for $172.08 \pm 17.08 \mu \mathrm{g} . \mathrm{g}^{-1}$ and $654,10 \pm 68.05 \mu \mathrm{g} . \mathrm{g}^{-1}$, respectively. When the same samples were analyzed in a UV/visible light spectrometer, the amounts of total carotenoids and of chl $a$ were $162.93 \pm 16.15 \mu \mathrm{g} \cdot \mathrm{g}^{-1}$ and
$665.22 \pm 65.35 \mu \mathrm{g} . \mathrm{g}^{-1}$. No significant differences were observed between the total amounts obtained using HPLC and UV/visible light spectrometry.

The carotenoids identified in $G$. tenuistipitata var. liui were zeaxanthin, $\beta$-carotene and $\beta$-cryptoxanthin (Table 5). Anteraxanthin, violaxanthin and lutein were not detected, differently from the results obtained by Pinto et al. (2011) in a study on the same seaweed species. Carnicas et al. (1999) likewise detected neither anteraxanthin nor violaxanthin, though lutein was present in the samples the authors analyzed. $\beta$ cryptoxanthin was not detected in either study.

Zeaxanthin was the main carotenoid in the samples analyzed in the present study, while the lowest concentration of a carotenoid was that of $\beta$ cryptoxanthin. Its levels varied considerably between repeats, and in some individual analyses this carotenoid was not even detected. Mean zeaxanthin content was $112.61 \pm 10.93 \mu{\mathrm{g} . \mathrm{g}^{-1}}^{-}$a value 1.9 times higher than the amount of $\beta$-carotene $(59.47 \pm 6.15$ g. $\left.g^{-1}\right)$.

Mean chl $a$ level was $654.11 \pm 68.08 \mu \mathrm{g} \cdot \mathrm{g}^{-1}$, 5.8 times as high as that of zeaxanthin. Pinto et al. (2011) and Carnicas et al. (1999) detected lutein and zeaxanthin, respectively, as the main carotenoids in the samples analyzed. These differences in pigment composition between studies give reliable evidence that carotenoids respond distinctively to growth conditions. Although it is widely known that these substances are quite sensitive to environmental changes, the methodological differences in the studies cited may actually be the principal reason behind the variable pigment composition reported therein.

Table 3. Mean total carotenoids and chl $a$ levels in Gracilaria tenuistipitata var. liui. Zhang and Xia fresh biomass $\left(\mu \mathrm{g} . \mathrm{g}^{-1}\right)$ obtained using different amounts of biomass. Values are presented as mean \pm standard deviation for $n=3$. Values followed by one same letter in a column do not differ (one-factor ANOVA and Tukey test, $p<0.05)$.

\begin{tabular}{lcccc}
\hline \hline & \multicolumn{2}{c}{ Mean levels $(\mu \mathrm{g})$} & \multicolumn{2}{c}{ Mean levels $\left(\mu{\left.\mathrm{g} . \mathrm{g}^{-1}\right)}\right.$} \\
\hline \multicolumn{1}{c}{ Mass $(\mathrm{mg})$} & Carotenoid & Chl $a$ & Carotenoids & Chl $a$ \\
\hline 25 & $3.50 \pm 0.29^{\mathrm{a}}$ & $14.14 \pm 1.18^{\mathrm{a}}$ & $140.21 \pm 11.69^{\mathrm{b}}$ & $565.90 \pm 47.26^{\mathrm{d}}$ \\
50 & $8.85 \pm 0.37^{\mathrm{b}}$ & $35.75 \pm 1.48^{\mathrm{b}}$ & $177.08 \pm 7.46^{\mathrm{a}}$ & $715.18 \pm 29.73^{\mathrm{c}}$ \\
100 & $15.92 \pm 0.83^{\mathrm{c}}$ & $68.23 \pm 3.13^{\mathrm{c}}$ & $159.20 \pm 8.35^{\mathrm{ab}}$ & $682.34 \pm 31.31^{\mathrm{c}}$ \\
\hline
\end{tabular}

Table 4. Mean total carotenoids and chl $a$ levels in Gracilaria tenuistipitata var. liui. Zhang and Xia fresh biomass $\left(\mu \mathrm{g} . \mathrm{g}^{-1}\right)$ obtained using different numbers of extractions. Values are presented as mean \pm standard deviation for $n=3$. Values followed by the same letter in a column do not differ (one-factor ANOVA and Tukey test, $p<0.05$ ).

\begin{tabular}{lll}
\hline \hline Extraction steps & Total carotenoids $\left(\mu \mathrm{g} \cdot \mathrm{g}^{-1}\right)$ & Chl $a\left(\mu \mathrm{g} \cdot \mathrm{g}^{-1}\right)$ \\
\hline 1 & $162.93 \pm 16.15^{\mathrm{a}}$ & $665.22 \pm 65.35^{\mathrm{b}}$ \\
2 & $168.95 \pm 16.36^{\mathrm{a}}$ & $688.52 \pm 64.86^{\mathrm{b}}$ \\
3 & $172.61 \pm 16.82^{\mathrm{a}}$ & $699.77 \pm 66.38^{\mathrm{b}}$ \\
\hline
\end{tabular}


Table 5. Characteristics of the pigments identified by HPLC-MS in extracts of Gracilaria tenuistipitata var. liui. Zhang and Xia.

\begin{tabular}{|c|c|c|c|c|c|c|c|c|c|}
\hline $\mathrm{t}_{\mathrm{R}}(\min )$ & pigment & & $\lambda_{\max }$ & $\mathrm{nm})^{\mathrm{a}}$ & & $\%$ & $\%$ & {$[\mathrm{M}+\mathrm{H}]^{+}(\mathrm{m} / \mathrm{z})$} & Ion fragments MS/MS \\
\hline $\begin{array}{l}14.3- \\
14.4\end{array}$ & all-trans-zeaxanthin & & 425 & 450 & 477 & 33 & 0 & 569 & $\begin{array}{l}551[\mathrm{M}+\mathrm{H}-18]^{+}, 533 \\
{[\mathrm{M}+\mathrm{H}-18-18]^{+}}\end{array}$ \\
\hline 16.4 & chl a & 338 & 432 & 620 & 665 & n. $d^{\mathrm{d}}$. & n.d. & 893 & $615[\mathrm{M}+\mathrm{H}-278]^{+}$ \\
\hline 23.0 & $\begin{array}{l}\text { all-trans- } \beta \text { - } \\
\text { cryptoxanthin }\end{array}$ & & 421 & 451 & 477 & 40 & 0 & 553 & $535[\mathrm{M}+\mathrm{H}-18]^{+}$ \\
\hline 34.0 & all-trans- $\beta$-carotene & & 422 & 451 & 478 & 30 & 0 & 537 & $\begin{array}{l}481[\mathrm{M}+\mathrm{H}-56]^{+}, 444 \\
{[\mathrm{M}+\mathrm{H}-92]^{+}}\end{array}$ \\
\hline
\end{tabular}

${ }^{\mathrm{a}}$ maximum absorption wavelength; ${ }^{\mathrm{b}}$ degree of fine structure $(\% \mathrm{III} / \mathrm{II}) ;{ }^{\mathrm{c}}$ cis intensity peak $\left(\% \mathrm{~A}_{\mathrm{B}} / \mathrm{A}_{\mathrm{II}}\right) ;{ }^{\mathrm{d}}$ not determined (n.d.).

\section{ConClusion}

In the present study, we suggest as standard protocol to extract carotenoids and chl $a$ from $G$. tenuistipitata var. liui the addition of $1.5 \mathrm{~mL}$ of methanol to $50 \mathrm{mg}$ of fresh biomass pulverized in liquid nitrogen; the mixtures must be vortexed and centrifuged; the extracts obtained shall be immediately analyzed by UV/visible light spectrophotometry and/or HPLC.

The results indicate that the solvent used is an important aspect of pigment extraction efficiency. Methanol was the most effective solvent. Apart from chl $a$, zeaxanthin, $\beta$-carotene and $\beta$-cryptoxanthin were also detected. No significant differences were observed between pigment amounts analyzed by UV/visible light spectrometry, a less expensive technique commonly available in most laboratories, and HPLC, a more sophisticated and more expensive one. However, the characterization of the different carotenoids detected and the determination of the respective levels require HPLC or even HPLC-MS.

\section{ACKNOWLEDGEMENTS}

The authors thank FAPESP (Fundação de Amparo à Pesquisa do Estado de São Paulo) for their financial support (2010/02948-3), and CNPq (Conselho Nacional de Desenvolvimento Científico e Tecnológico) for PBT fellowship.

\section{REFERENCES}

ARVAYO-ENRÍQUEZ, H.; MONDACA-FERNÁNDEZ, I.; GORTÁREZ-MOROYOQUI, P.; LÓPEZCERVANTES, J.; RODRÍGUEZ-RAMÍREZ, R. Carotenoids extraction and quantification: a review. Anal. Methods, v. 5, p. 2916-2924, 2013.

BORSARELLI, C.; MERCADANTE, A. Thermal and photochemical degradation of carotenoids. In:
LANDRUM, J. T. (Ed.). Carotenoids: physical, chemical, and biological functions and properties. Boca Raton: Taylor \& Francis Group, 2010. p. 229-253.

CARNICAS, E.; JIMÉNEZ, C.; NIELL, F. X. Effects of changes of irradiance on the pigment composition of Gracilaria tenuistipitata var. liui Zhang et Xia. J. Photochem. Photobiol., B, v. 50, n. 2/3, p. 149-158, 1999.

EDWARDS, P. Illustrated guide to the seaweeds and sea grasses in the vicinity of Porto Aransas, Texas. Contrib. Mar. Sci., v. 15, p. 1-228, 1970.

FARIA, A. F.; HASEGAWA, P. N.; CHAGAS, E. A.; PIO, R.; PURGATTO, E.; MERCADANTE, A. Z. Cultivar influence on carotenoid composition of loquats from Brazil. J. Food Compos. Anal., v. 22, n. 3, p. 196-203, 2009.

GAUTHIER-JAQUES, A.; BORTLIK, K.; HAU, J.; FAY, L. B. Improved method to track chlorophyll degradation. J. Agric. Food Chem., v. 49, n. 3, p. 1117-1122, 2001.

GUEDES, A. C.; AMARO, H. M.; MALCATA, F. X. Microalgae as sources of carotenoids. Mar. Drugs, v. 9, n. 4, p. 625-644, 2011.

ISHIDA, B. K.; CHAPMAN, M. H. Carotenoid extraction from plants using a novel, environmentally friendly solvent. J. Agric. Food Chem., v. 57, n. 3, p. 10511059, 2009.

JEFFREY, S. W.; HUMPHREY, G. New spectrophotometric equations for determining chlorophylls a, b, c1 and c2 in higher plants, algae and natural phytoplankton. Biochem. Physiol. Pflanz., v. 649, n. 1, p. 105-149, 1975.

KELMAN, D.; POSNER, E. K.; MCDERMID, K. J.; TABANDERA, N. K.; WRIGHT, P. R.; WRIGHT, A. D. Antioxidant activity of Hawaiian marine algae. Mar. Drugs, v. 10, n. 2, p. 403-16, 2012.

KHACHIK, F. Analysis of carotenoids in nutritional studies. In BRITTON, G.; LIAAEN-JENSEN, S.; PFANDER, D. H. (Eds.). Nutrition and health. Basel: Boston: Berlin: Birkhäuser, 2009. p. 7-44. (Carotenoids; v. 5).

KOPEC, R. E.; COOPERSTONE, J. L.; CICHON, M. J.; SCHWARTZ, S. J. Analysis methods of carotenoids. In: XU, Z.; HOWARD, L. R. (Eds.). Analysis of antioxidant-rich phytochemicals. Hoboken: Chichester: Wiley-Blackwell, 2012. p.105-149.

KOPECKY, J.; SCHOEFS, B.; LOEST, K.; STYS, D.; PULZ, O. Microalgae as a source for secondary carotenoid production: a screening study. Arch. Hydrobiol., Suppl., v. 133, p. 153-168, 2000. 
LICHTENTHALER, H. K.; BUSCHMANN, C. Chlorophylls and carotenoids: measurement and characterization by UV-VIS. In: WROLSTAD, R. E.; ACREE, T. E.; DECKER, E. A.; PENNER, M. H.; REID, D. S.; SCHWARTZ, S. J.; SHOEMAKER, C. F.; SPORNS, P. Current protocols in food analytical chemistry. New York: John Wiley, 2001. p. F4.3.1-F4.3.8.

MARINHO-SORIANO, E. Effect of depth on growth and pigment contents of the macroalgae Gracilaria bursapastoris. Rev. Bras. Farmacogn., v. 22, n. 4, p. 730 735, 2012.

PINTO, E.; CARVALHO, A. P.; CARDOZO, K. H. M.; MALCATA, F. X.; ANJOS, F. M.; COLEPICOLO, P. Effects of heavy metals and light levels on the biosynthesis of carotenoids and fatty acids in the macroalgae Gracilaria tenuistipitata (var. liui Zhang \& Xia). Rev. Bras. Farmacogn., v. 21, n. 2, p. 349-354, 2011.

RAVEN, P. H.; EVERT, R. F.; EICHHORN, S. E. Biologia vegetal. 7. ed. Rio de Janeiro: Guanabara Koogan, 2007. $830 \mathrm{p}$

ROSSO, V. V.; MERCADANTE, A. Z. Identification and quantification of carotenoids, by HPLC-PDA-MS/MS, from Amazonian fruits. J. Agric. Food Chem., v. 55, n. 13, p. 5062-5072, 2007.

SCHMIDT, É. C.; MARASCHIN, M.; BOUZON, Z. L. Effects of UVB radiation on the carragenophyte Kappaphycus alvarezii (Rhodophyta, Gigartinales): changes in ultrastructure, growth, and photosynthetic pigments. Hydrobiologia, v. 649, n. 1, p. 171-182, 2010.
VAN BREEMEN, R. B.; DONG, L.; PAJKOVIC, N. D. Atmospheric pressure chemical ionization tandem mass spectrometry of carotenoids. Int. J. Mass Spectrom., v. 312, p. 163-172, 2011.

WELLBURN, A. R. The spectral determination of chlorophylls $a$ and $b$, as well as total carotenoids, using various solvents with spectrophotometers of different resolution. J. Plant Physiol., v. 144, n. 3, p. 307-313, 1994.

WRIGHT, S. W.; JEFFREY, S. W.; MANTOURA, R. F. C. Evaluation of methods and solvents for pigment extraction. In: JEFFREY, S. W.; MANTOURA, R. F. C.; WRIGHT, S. W. (Eds.). Phytoplankton pigments in oceanography: guidelines to modern methods. Paris: UNESCO, 1997. p. 261-282. (Monographs on oceanographic methodology; 10).

URSI, S.; PLASTINO, E. M. Crescimento in vitro de linhagens de coloração vermelha e verde clara de Gracilaria birdiae (Gracilariales, Rhodophyta) em dois meios de cultura: análise de diferentes estádios reprodutivos. Rev. Bras. Bot., v. 24, n, 4, supl., p. 587$594,2001$.

(Manuscript received 07 August 2013; revised 09 March 2014; accepted 18 March 2014) 